\title{
Atypical Presentation of Renal Cell Carcinoma in a Child
}

\author{
J. Devkotg, M.D. \\ Kirksville, Missouri
}

DOI: http://dx.doi.org/10.5915/22-3-14308

\begin{abstract}
Absiract
Renal cell carcinoma is a rare malignancy in the pediatric age group whereas it is a more common lesion in older adults. Wilm's lumiors oul number renal cell carcinomas by a rario of 30: I in children. There have been less than 175 cases of pediatric renal cell carcinoma reported in the Engilsh literolure 10 dale. Besides being an uncommon lesion, an unusual mode of presentation at the time of the diagnosis, ond diagnostic imaging appearance of this case makes it even more interesling. The usual signs and symploms of painless gross hemaruria, flank pain, insidious fever, and infections, as well as helerogenous and ill-defined margins, were complecely locking.
\end{abstract}

Key words: Renal cell carcinomu, adenocarcinoma, pediarric renal cell carcinoma, renal malignancy.

A 9-year-old male woke up one morning with severe acute abdominal pain. He had enjoved good healih until two days before. For the preceding iwo days he had received antibiolics and decongestants for a common cold. His temperature was found co be $104^{\circ} \mathrm{F}$. During the next few hours his pain became worse and he was laken to the emergency room. At the ER, the pliysician found no unusual symptoms except the fever. The abdomen was soft and without guarding but the child complained of excruciating pain in the right upper quadrant. Laboralory tests including complete blood work, urine analysis, and abdominal radiographs were unremarkablc. The physician suspecied acule cholecystiris and requested an ultrasound examination of the gall bladder. This showed the gall bladder to be normal, but licere was a dense, round, well-defined, smoolh bordered mass in the lower pole of the right kidney. The mass was sur-

From the Depariment of Radiology

Grim-Smith Hospital

Kirksuille. Missouri.

Reprint Requesis: J. Devkola. M,D.

Deparimenl of Rodiology

Grim-Smilh Haspiral

Kirksville, MO 6350!. rounded by an echoless balo. (Figure 1) To confirm the nature of the vascularity and to rulc out involvemenc of surrounding struciures compuced tomograplyy (CT) was performed. This again revealed the solid, hypovascular, homogenous, regular shaped mass. (Figure 2) No vascular pedicle or lymph nodes were involved. The child underwent surgery and frozen sections showed an undelermined malignancy. A radical right nephrectomy and $\mathrm{ex}$ ploration of the surrounding area were performed. No other structures were involved. The child tolerated the procedure well and had an uneventful recovery. His pain subsided. The tumor was classified as stage I. On permanent section, it was found to be adencarcinoma.

\section{Discussion}

Data compiled in the third National Cancer Survey indicared that renal malignancy ranks $6 \mathrm{~h}$ in frequency among all childhood cancers, with Wilm's tumor laking the major proportion. "2 Renal cell carciriona comprises about $7 \%$ of all primary intrarenal cancers in persons under the age of 21 years. Raney reported on the largest series of cases (20) in 1983, collected from four oncology ceniers.' Lack et al reported on 17 cases during 29 years in the Children's Hospital and Dana Farber Cancer Insciute (Bossun).' 


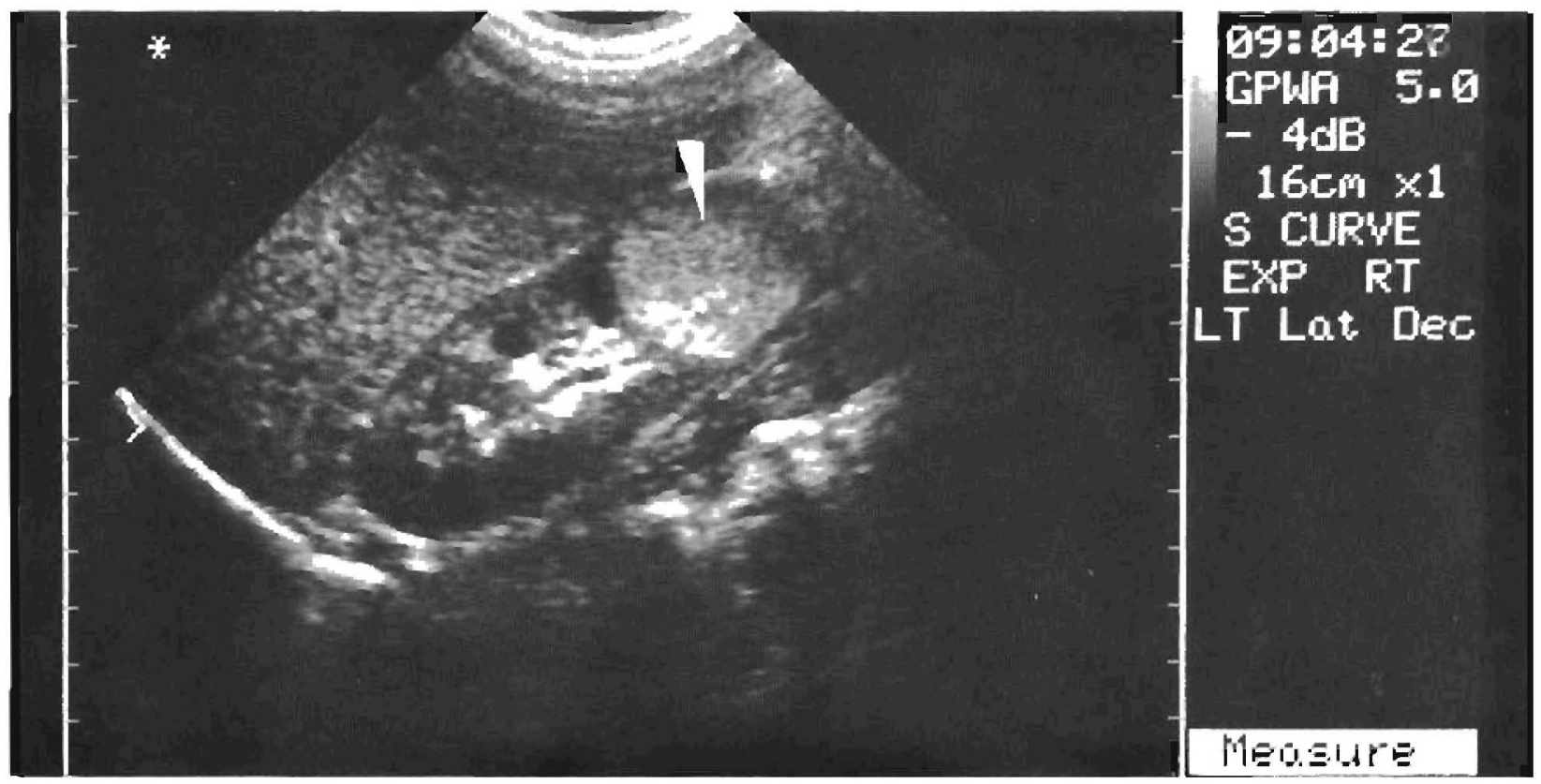

Figure 1. Longitudinal sector scan of the right kidney shows a dense, circumscribed mass, well situated within the lower pole of the right kidney. A faint halo surrounds the mass. (whice arrow).

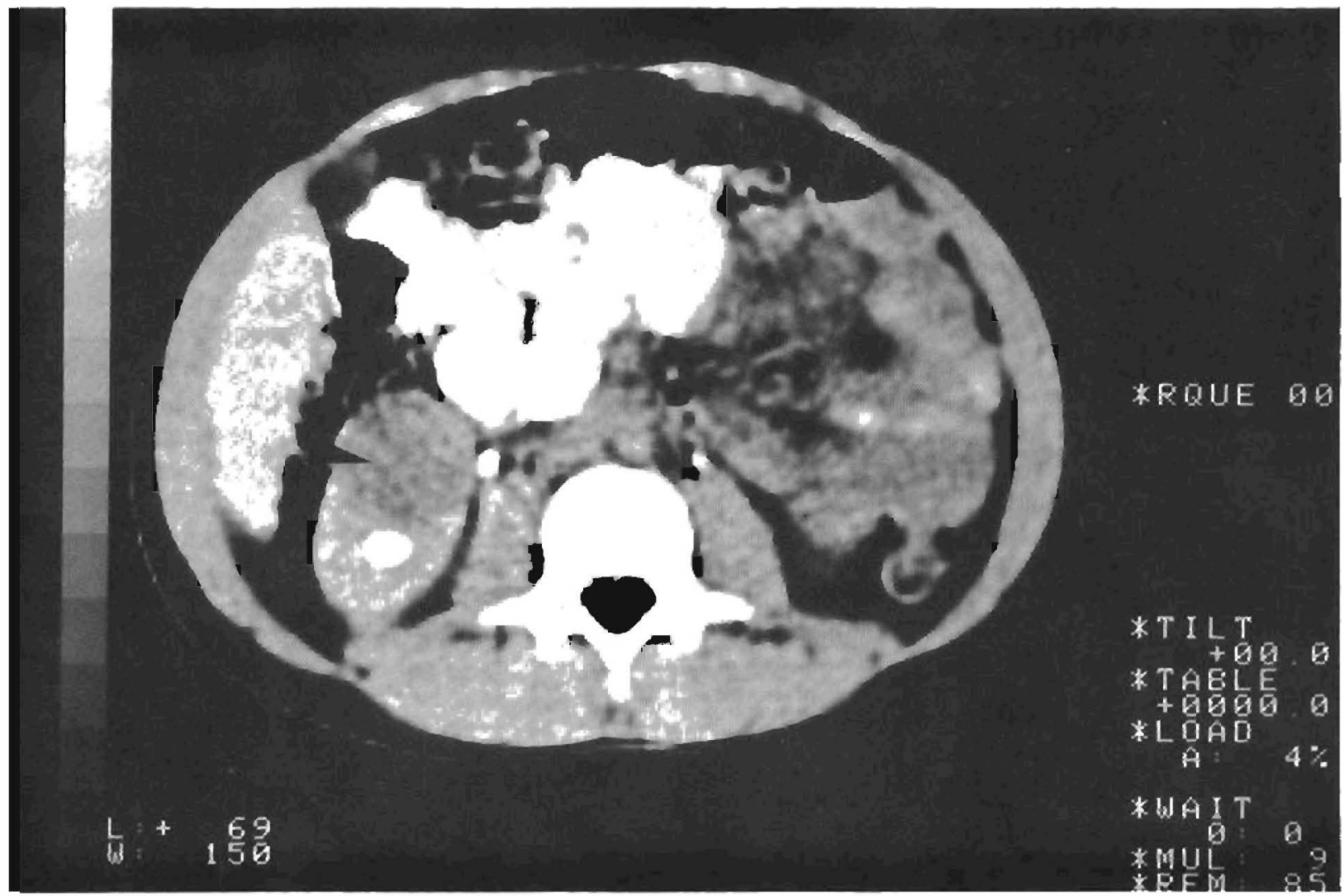

Figure 2. Transverse CT scan shows a hypodense, hypovascular, well-defined mass in the lower pole of the right kidney (black arrow). There is no extension outside the renal capsule. 
The childhood renal cell carcinoma looks similar 10 aduh lypes bul their growch pattesn, rate of growth, and prognosis are unpediclable.' There is a natural !endency 10 metastasize 10 lungs, bones, and para-aorlic lymph nodes.

Mast of the children seported in the literature had been sympromatic for some time and had received ireacments for symploms related 10 the urinary Iract. 'Also in the literature there is emphasis on poorly defined borders and heterogenicily of the lesion. At times, these cancers are confused wich renal cysts. 'Our case was unique due to lice fact that it was well-defined, smoolh, and had all criterla of a benign umor. Al the lime, it was considered 10 be a hemaroma. The child had no symproms pertasning 10 the urinary isact. Violent upper quadranc pain without previous illness is considered a very unusual presencation.

The trealment of choice for slage 1 renal cell carcinoma in clildren is radical nephreciomy followed by radiation therapy. Due to the rarity of the lesion and lack of prospective randomized siudies, recommendation of adjuvanl (hecapy for uncomplicared cases remains 10 be proven. For some advanced slages, post operative radiation therapy has been utilized; however, there is no proven curalive regunen.'

Posl opcrarjve local radiation was suggested, bul duc 10 complete removal of the well detined mass and the absence of any sign of vasculas pedicle or capsular invasion, it was decided nor 10 intialed either radialion or chemolherapy, and to follow him closely wilh lime interval check ups, ultrasound, and CT scans. The child completely recovered from the surgery and resurned to school. At a six month follow-up visil, he was found to be in good condition with 110 sign of rceucrence.

\section{References}

1. Lack R, Cassady JR, Sallan S. Renal cell carinoma in childhood and adolescence: A clinical and pathological study of 17 cases. J Urology. 1985:133:822-8.

2. Young JL. Miller RW. Incidence of malignant tumors in U S. children. I Ped. 1975;86:254-8.

3. Raney BR, Palmer $N$, Sulow WW, Baum E. Renal cell carcinoma in childrer. Med Ped Oncol.1983;11: $91-8$.

4. Coleman BG. Arger PH, Mulhern CB, Pollack HM, Banner MP. Arenson RL. Gray-scale sonographic soectrum of hypernephromas. Rádiology. 1980:137:757-65. 